\title{
GAMETOPHYTE AND SPOROPHYTE OF TREE FERNS IN VITRO CULTURE
}

\author{
KATARZYNA GOLLER, JAN JAROSŁAW RYBCZYŃSKI \\ Botanical Garden - Center for Biological Diversity Conservation \\ Polish Academy of Sciences \\ Prawdziwka 2, 02-973 Warszawa, Poland \\ e-mail: katarzyna.goller@vp.pl
}

(Received: July 11, 2006. Accepted: March 12, 2007)

\begin{abstract}
Experiments had been carried out on gametophytes and very young fronds of sporophytes with application of Murashige and Skoog (1962) medium. The paper described the results of 15 years in vitro experiments on 16 species of tree ferns belonging to various genera: Blechnum, Cibotium, Cyathea and Dicksonia. Genus Cyathea was represented by: C. australis (R.Br.) Domin., C. capensis (L.f.) Sm., C. cooperi (F.Muell.) Domin, C. brownii Domin, C. dealbata (G.Forest) Sw., C. dregei Kunze, C. leichhardtiana (F.Muell.) Copel., C. robertsiana (F.Muell.) Domin., C. schanschin Mart., C. smithii Hook.f. and Cyathea sp. In case of genus Dicksonia only two species were introduced into our experiments: D. fibrosa Colenso and D. sellowiana Hook.. Taxa Blechnum was presented by B. brasiliense Desv. and Cibotium by C. glaucum (Sm.) Hook. and Arn. and C. schiedei Schltdl. and Cham..

The studied species presented various responses on culture conditions depending on the level of stage of development. Time required for spores germination differed between species and took from only a few to 16 weeks. Prothalium formations showed various types of growth presented by marginal meristems. For all investigated species long term gametophyte in vitro cultures was established. Mature gametophyte possessed functional antheridia and archegonia. Spontaneous fertilization helped to establish the culture of young sporophytes. For all species the ex vitro culture in greenhouse collection was established. Manipulation of sucrose content in the medium stimulated the multiplication of gametophytes, but its lack induced formation of gemmae. Apospory was observed when culture of very young fronds was extended for 6 months and new generation of gametophytes was developed. Finally, sporophytes of 12 species were obtained and they have been growing in our greenhouse.
\end{abstract}

KEY WORDS: apospory, gametophyte and sporophyte, gene bank, greenhouse collection, in vitro culture, multiplication, tree fern, spores.

\section{INTRODUCTION}

Tree ferns are typical for rain forest of tropical and subtropical climate. Because of their ornamental beauty they are usually used for out- and indoor decoration. The majority of tree ferns are illegally collected from natural sites, what resulted in decrease of their population, though they are listed on the International Red Book and protected by CITES (Etter 1993). They are excluded from official exchange programmes of plant material. This is the way of this plant species protection against total extinction (Tryon 1976). We estimate that the threats of the species are even higher; there are not many papers concerning vegetative propagation of the ferns over the world. However, we know that the gametophyte is the objective of studies conducted in the Institute of Forestry of Taiwan. Our involvement in the studies of tree fern multiplication dates back to the beginning of 90-ties of the twentieth century (Goller and Rybczyński 1995). In the meantime, with the application of in vitro culture of spores (obtained within the frame of the Botanical Garden Exchange Program) and consecutive stages of development, the system of plant material multiplication was developed. Young plants could be reintroduced to natural conditions, too (Gomez 1983; Kramer 1990). Now, we posses the next ten species in our gametophyte bank, together giving us the biggest collection of tree fern in Poland, and we hope in Europe, too. Plants carried on in our tropical greenhouse collection already reached maturity and they can serve as the source of spores for next experiments. At present, a lot of efforts is done to develop the system of cryopreservation of spores and gametophytes.

In the paper we would like to describe the morphological events which were observed in long term cultures of gametophytes and very young sporophytes of tree ferns.

\section{MATERIALS AND METHODS}

\section{Plant material}

Experiments were carried out with application of various stage of development of four genera of tree ferns; Blechnum, Cibotium, Cyathea and Dicksonia. Genus Cyathea 
was represented by: $C$. australis, $C$. capensis, $C$. cooperi, C. brownii, $C$. dealbata, C. dregei, C. leichhardtiana, C. robertsiana, C. schanschin, $C$. smithii and Cyathea sp. In case of genus Dicksonia only two species were introduced into our experiments: $D$. sellowiana and $D$. fibrosa. Taxa Blechnum was represented by $B$. brasiliense and Cibotium by $C$. glaucum and $C$. schiedei.

\section{Media used}

Murashige and Skoog's (1962) medium in various mineral salt concentrations supplemented with or without succrose was mainly used in our experiments.

\section{Plant material sterilization}

Spores and sporangia were sterilized with the application of $96 \%$ ethanol at $30 \mathrm{sec}$. and $3 \%$ chloramines during 10, min and at least three times washed with sterile distillated water.

\section{Sporangium and spores culture initiation}

The culture initiation consisted in sporangia and spores implantation on agar hormone-free 0.5 MS0 medium (half strength of mineral macroelements composition of medium). The culture was carried out with the help of sterile plastic Petri dishes in culture chamber with 16/8 hrs of day/light photoperiod and temperature $20 \pm 1^{\circ} \mathrm{C}$.

Maintenance of gametophytes

For long term culture, gametophytes were implanted to the $200 \mathrm{ml}$ jars with $40 \mathrm{ml}$ of medium. The culture extension stimulated the multiplication of gametophytes. Subcultures of plant material were species depended. Gametophytes of some species were subcultures many times during several years. Gametophytes were used for numerous other experiments describing their morphogenetic potential in relation to the supplementation of culture medium with sucrose (Table 1).

\section{Fertilization and sporophyte production}

The temperature changes of culture chamber stimulated water condensation on gametophytes and stimulated spontaneous fertilization. After a few months the primary leaves of sporophyte (fronds) were raised up and after next few months plantlets were rooted and transferred to the ex vitro condition. This stage of sporophyte development appeared to be an excellent source of young leaves for other experiments.

\section{Sporophytes hardening and their growth in greenhouse}

Hardening of sporophyte was gradually done with slow acclimatization to various humidity and temperature. Plants of two fronds stages were transferred to the pots in greenhouse nursery and after next two years they were implanted to the final ground position in greenhouse collection.

\section{Induction of the apospory}

Primary $4 \mathrm{~cm}$ long leaves of sporophytes were excised with the help of a fine knife and implanted into Petri plates with 0.5 MS medium supplemented with or without sucrose. The culture was maintained in the presence of light conditions described above during 9 to 12 months (Table 1).

\section{Methods of morphogenic events documentation}

For light microscopy, the selected plant material was analyzed without staining, using "Olympus" microscopes. The
TABLE 1. Steps of tree fern culture with proper and manipulated development of gametophyte and sporophyte.

\section{Pinnae with Sporangia}

$\downarrow \quad$ Collection

Spore

$\downarrow \quad$ Isolation and germination

Prothalium

$\downarrow \quad$ Cell multiplication and differentiation

Gemmae

Gametophyte

$\downarrow \quad$ Proliferation and multiplication Spontaneous fertilization

Embryo development

$\downarrow \quad$ Growth of first leaf

Sporophyte

$\downarrow \quad$ Growth in vitro culture

Apospory Sporophyte leaves culture

$\downarrow$

Sporophyte in vitro hardening

$\downarrow$

Sporophyte ex vitro hardening

$\downarrow$

Sporophyte pot culture

$\downarrow$

Sporophyte soil culture and getting maturity

scanning electron microscope studies of gametophytes were performed with explants collected every seven days during consecutive 8 weeks. Cultures were fixed with $2.5 \%$ glutaraldehyde in 0.1 mol..$^{-1}$ cacodylate buffer at $\mathrm{pH}=7.0$ for $2 \mathrm{hrs}$ and $1.0 \% \mathrm{OsO}_{4}$ in $0.2 \mathrm{M} \mathrm{Na}$-cacodylate for $24 \mathrm{hrs}$. After four times washing of buffers: cacodylate and phosphate (15 min each), plant material was transferred to the series of alcohols from $10 \%$ to $100 \%$ for $15 \mathrm{~min}$. for dehydratation. Alcohol was substituted by acetone with the application of mixture of both substances in proportion 3:1, 1:1, 1:3 for $30 \mathrm{~min}$ for each washing. For dehydratation, the samples were placed in microporus specimen capsules and dried with liquid $\mathrm{CO}_{2}$ in a critical point dryer Type E 31000 Jumbo Series II, Polaron Equipment LID. Samples were coated with gold using a Coater "Jeol". Finally, the samples were analyzed by means of a scanning electron microscope model JSM-S1.

\section{RESULTS AND DISCUSSION}

\section{Plant material disinfection and spore germination}

For more then 10 years, since the first of our papers has been published (Goller and Rybczyński 1995), not much 
TABLE 2. The list of species which gametophyte cultures have been carried on during last few years.

\begin{tabular}{|c|c|c|c|c|c|c|}
\hline No. & Species & $\begin{array}{c}\text { Time of } \\
\text { germination (weeks) }\end{array}$ & $\begin{array}{l}\text { Gametophyte } \\
\text { (weeks) }\end{array}$ & $\begin{array}{l}\text { Sporophyte } \\
\text { (months) }\end{array}$ & Apospory & $\begin{array}{c}\text { Ex vitro / } \\
\text { / greenhouse collection }\end{array}$ \\
\hline 1. & Blechnum brasiliense Desv. & 7 & 12 & 8 & Not studied & + \\
\hline 2. & Cibotium glaucum (Sm.) Hook. and Arn. & 4 & 12 & - & - & - \\
\hline 3. & Cibotium schiedei Schltdl. and Cham. & 5 & 8 & 6 & Not studied & + \\
\hline 4. & Cyathea australis (R.Br.) Domin. & Dry - 16; Fresh -4 & 16 & 12 & Not studied & + \\
\hline 5. & Cyathea brownii Domin. & 8 & 8 & 5 & Not studied & + \\
\hline 6. & Cyathea capensis (L.f.) Sm. & 14 & 20 & 14 & - & - \\
\hline 7. & Cyathea cooperi (F.Muell.) Domin. & 16 & 16 & 12 & Not studied & + \\
\hline 8. & Cyathea dealbata (G.Forest) Sw. & 4 & 8 & 6 & + & - \\
\hline 9. & Cyathea dregei Kunze & 8 & 12 & - & - & - \\
\hline 10. & Cyathea leichhardtiana (F.Muell.) Copel. & 6 & 8 & 6 & + & + \\
\hline 11. & Cyathea robertsiana (F.Muell.) Domin. & 5 & 8 & 5 & Not studied & + \\
\hline 12. & Cyathea schanschin Mart. & 8 & 8 & 5 & + & + \\
\hline 13. & Cyathea smithii Hook. f. & 8 & 8 & 4 & + & + \\
\hline 14. & Cyathea sp. & 12 & 16 & 4 & Not studied & + \\
\hline 15. & Dicksonia fibrosa Colenso & 8 & 8 & 5 & + & + \\
\hline 16. & Dicksonia sellowiana Hook. & 4 & 6 & 6 & Not studied & + \\
\hline
\end{tabular}

publications concerning tissue culture of tree fern were released. Table 2 summarizes our experiments carried out on material originating from various sources - botanical gardens within the frame of the International Seeds Exchange Program. The response of spores for in vitro culture conditions resulted in prothalium production (Figs 1A-D). We observed that the time required for spore germination into prothalium depended on application of the disinfection solution, however, we are sure that the type of storage in institution of spores origin affected their viability and power germination, too. Domestos, commercial bleach, appeared more effective in sterilization and spore germination than the initially used chloramine. It was shown that the type of disinfection substance had a significant effect on Cyathea delgadii spore germination (Simabukuro et al. 1998). Dyer (1979) tested numerous sterilization solutions such like $\mathrm{NaOCL}, \mathrm{Ca}(\mathrm{OCL})_{2} \cdot 4 \mathrm{H}_{2} \mathrm{O}$, and concluded that the majority of disinfectors of fungi and bacteria extend the time required for spore germination and decrease their viability. The spore germination depended on species and viability of the received material. According to Page (1979) in the majority of Cyatheaceae species the spore germination abilities decrease after a few weeks of storage, what is typical for tropical plants. For example, Cyathea delgadii spores lost their viability for germination during two months at $12^{\circ} \mathrm{C}$ in the presence of low humidity (Randi and Felippe 1988), and the percent of germinated spores decreased during the next six months (Marcondes-Farreira and Felippe 1984). Constantino et al. (2000) distinguished two types of tree fern spores: chlorophyll and non-chlorophyll. The chlorophyll ones did not show the state of spore dormancy, and germinated almost directly after 1.46 day and possessed viability for 48 days. Non-chlorophyll spores germinated after 9.5 days and their viability was carried out during 10-45 days. (Lloyd and Klekowski 1970). For Cyathea caracasana and Dicksonia sellowiana, non-chlorophyll spore species, the longest time of storage was completed during 11 and 13 months, respectively.

Freshly isolated spores collected from sporangia of Cyathea australis, growing in our greenhouse, directly implanted on the medium germinated during four and six weeks.

\section{Gametophyte culture}

Gametophyte overgrowth and development was initiated by spore germination and formation of multicellular prothalium structure (Figs 1A-D) on 0.5 MS medium supplemented with sucrose. In case of $C$. robertsiana sporangium implantation the spore germination response was noticed. As the effect of overgrowth, the primary shape of young gametophyte was reached (Figs 1E, G). Finally a heart-shaped gametophyte was formed as the result of edge meristem cells activity (Fig. 1F), expressed by increase of the cell number and the surface of that generation (Fig. 1G). The culture extension for next two months resulted in initiation of proliferation of gametophyte (Figs $1 \mathrm{G}, \mathrm{H}$ ). In the presence of $0.5 \mathrm{MS}$ (1962) medium, the process of spontaneous gametophyte allowed to form a colony of multi and individual gametophytes (Figs $1 \mathrm{H}, \mathrm{I})$. The alternative system of gametophyte proliferation, to get their bulk production, could be obtained with the application of their immobilization (Douglas and Sheffield 1990). SEM analysis of C. brownii (Fig. 2) improved the involvement of the whole gametophyte in its spontaneous proliferation. Their maturity was expressed by sexual organs' formation, and Figure 3 presents rich formation of antheridia.

\section{Gemmae formation}

Individual gametophytes excised from multi-gametophyte structure of $C$. dealbata, $C$. leichhardtiana, $C$. schanschin and $C$. smithii derived from many year-old cultures were maintained on 0.5 MS0 medium without sucrose. During two months of culture on the edge of gametophytes numerous intensive green centers were formed as the result of meristematic activity of the marginal cells. These green centers called "gemmae" and developed in new generation of gametophyte when implanted on the medium supplemented with sucrose. Our results confirmed the earlier description of such structure in Osmunda regalis cultures (Fernandez et al. 1997). Figure 4 shows the initial and mature stages of gemmae with typical for this structure rich rhizoids. The obtained new generation of gametophytes presented sexual maturity, confirmed by formation of numerous antheridia and archegonia. With help of UV light 

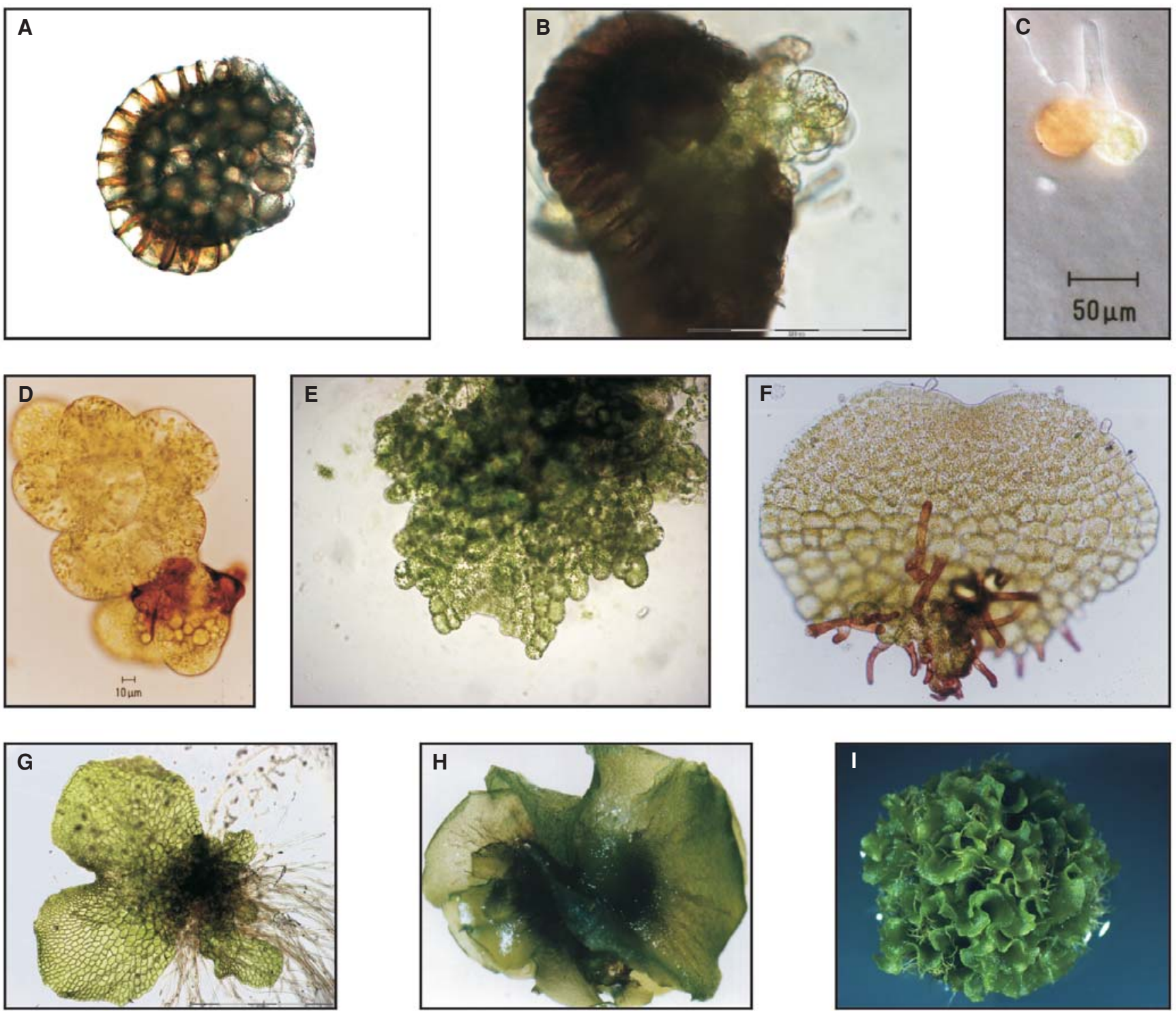

Fig. 1. Development, growth and vegetative multiplication of gametophyte of tree ferns on half strength of Murashige and Skoog (1962) medium $+3 \%$ sucrose. A - single sporangium with viable $C$. robertsiana spores; B - open sporangium with spreading C. leichhardtiana spores; C - initial stage of spore germination of C. australis; D - multicellular non-organized prothalium of $C$. australis; $\mathrm{E}$ - formation of edge meristem of $C$. robertsiana prothalium; $\mathrm{F}-$ heart stage of $C$. australis gamethophyte; $\mathrm{G}$ - proliferation of $\mathrm{C}$. leichhardtiana gamethophyte; $\mathrm{H}$ - overgrowth of initially multiple gamethophyte of $C$. australis after two months of culture; I - "Colony" of $C$. dealbata gamethophyte after 6 months of culture

and special filters the structure of antheridia and mature sperm cells could be detected.

\section{Apospory induction}

The initial response of very young, primary leaves of $C$. dealbata, C. leichhardtiana, $C$. schanschin, $C$. smithii and $D$. fibrosa, on medium without sucrose, consisted in showing color changes from pale yellow to deep brown during four weeks of the culture. The extension of the culture for next two months did not change the response of explants. After next six months of culture only in case of Cyathea species about $50 \%$ of explants responded by the overgrowth of the basal part of leaves. Its overgrowth resulted in proliferation of green gametophytes, finally partly covering part of the explant (Fig. 5). Microscopic analysis revealed that initially the chloroplasts were intensively gathered in the ridge cells and later on the cell division of vegetative part of gametophyte, resulted in spontaneous gametophyte multiplication. The lack of sucrose in the medium helped to induce apospory (Hirsch 1975; Zenkteler 1995). Hirsch (1975) described the response of young leaves of Microgramma vacciniifolia on sucrose concentration in the medium. The presence of $3 \%$ sucrose induced only sporophytes regeneration on the frond surface, however, its lack in the medium causes gametophytes and sporophytes occurrence on the edge of frond.

\section{Young sporophyte hardening and greenhouse culture}

In the jar conditions, because of high humidity, spontaneous fertilization took place as the result of independent translocation of sperm cells to archegonium. Figure 6A shows the intensity of sporophyte production by the colony of gametophyte. One month of the culture resulted in formation of new plantlets with 3-4 fronds. Usually such plantlets possessed a few roots (Fig. 6B), and transferred to the perlite with liquid medium, developed a good enough root system (Goller and Rybczyński 1995). Gradual decreasing of humidity of the culture played an important role in plant adaptation for 

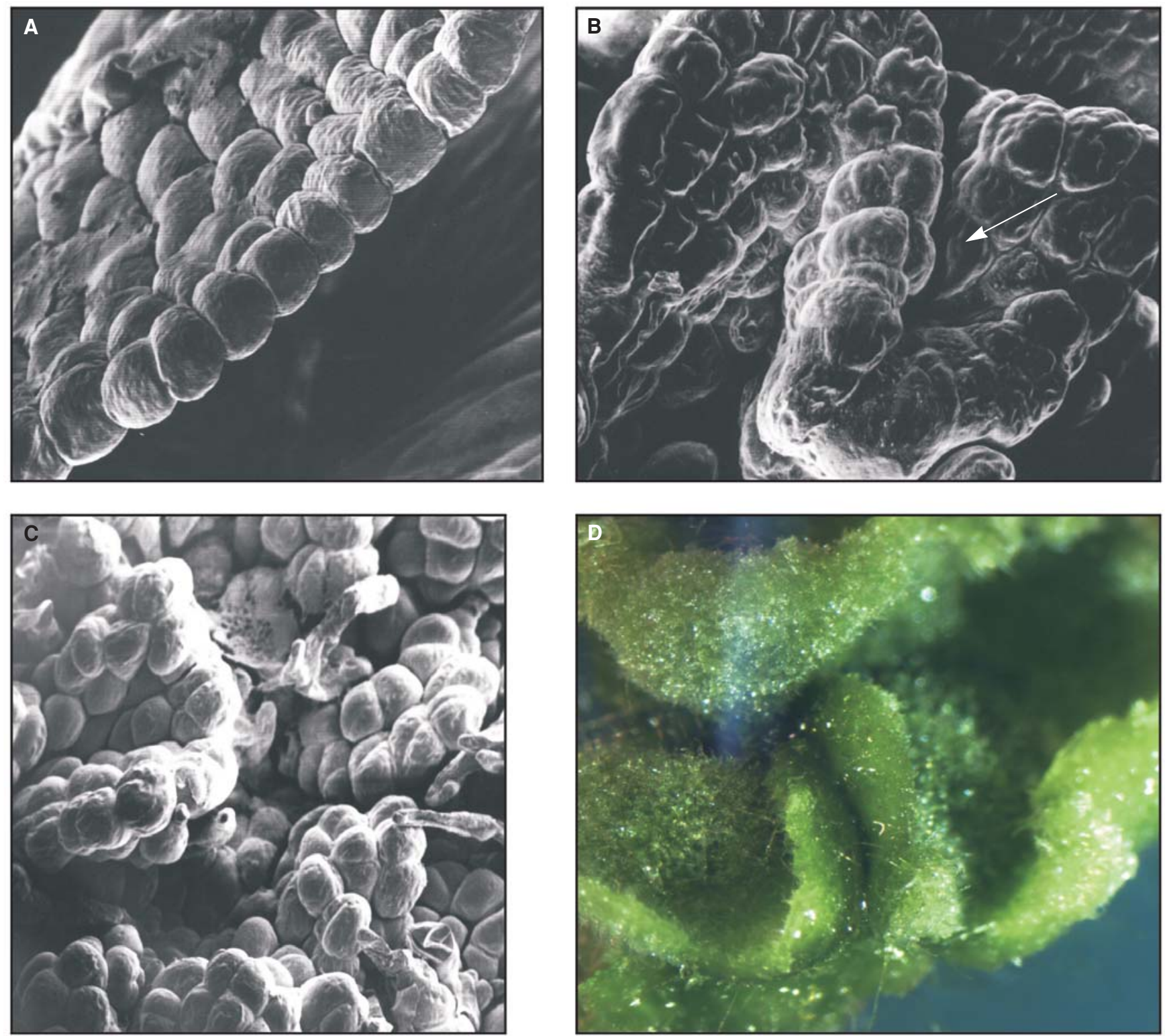

Fig. 2. Proliferation of Cyathea brownii gametophyte on half strength of Murashige and Skoog (1962) medium + 3\% sucrose. A - typical one cell layer structure of the vegetative part of gametophyte (SEM); B - multicellular edge of gametophyte (SEM); C - SEM analysis of gametophyte proliferation and initial stage of multiplication of gametophyte; D - gametophyte cell proliferation in vitro
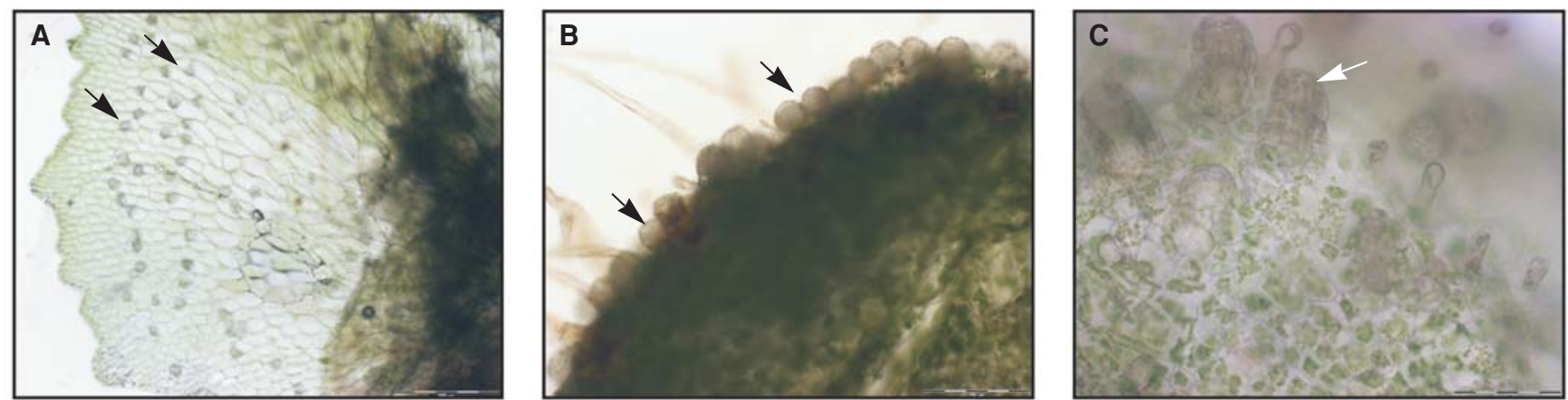

Fig. 3. Gametangium of tree ferns. A - general view of C. leichhardtiana gametophyte with two lines of antheridia (MS + 3\% sucrose); B - numerous antheridia on the down side of $C$. schanschin gametophyte; $\mathrm{C}$ - single antheridum of $C$. schanschin

ex vitro conditions. Figures 6C, D presents particular stages of adaptation of plantlets from in vitro conditions up to growing mature plant in the greenhouse.

In conclusion, we can stress that gametophyte of tree ferns, can be used for studies of morphogenic events of ha- ploidal single cell layer, and utilized for multiplication of lower vascular plants since in vitro spontaneous fertilization and sporophytes development takes place. 

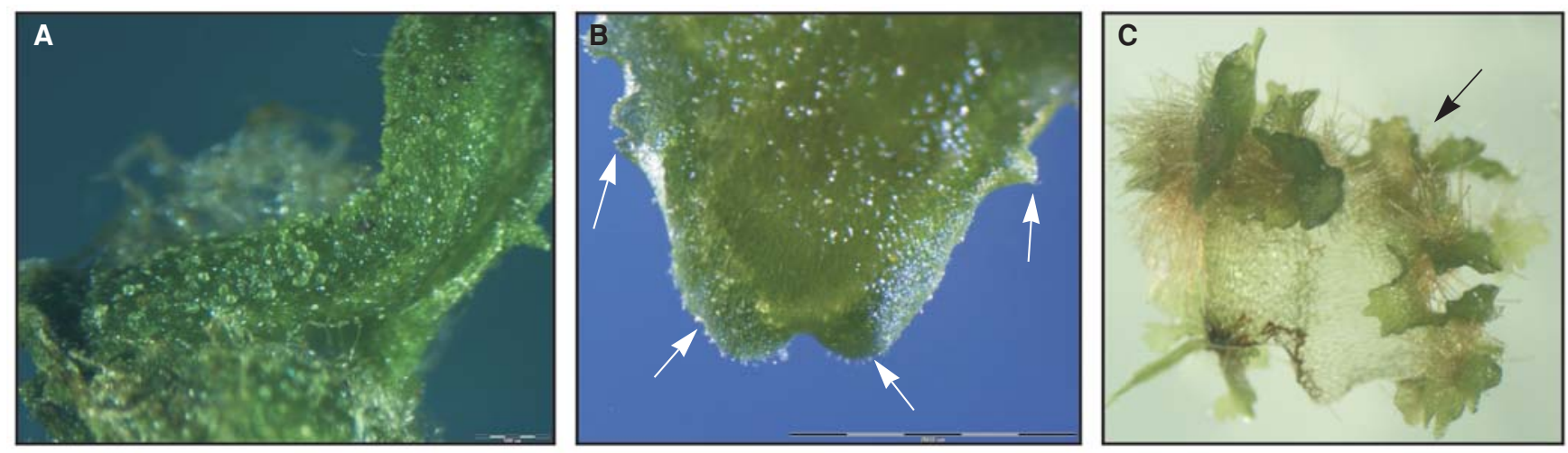

Fig. 4. Gametophyte response on 0.5 MS (1962) without sucrose medium. A - initial cell proliferation for "gemmae" formation of $C$. schanschin; B organization of green edge cell centers of $C$. schanschin; $\mathrm{C}$ - mature "gemmae" on overgrown gametophyte of $C$. dealbata
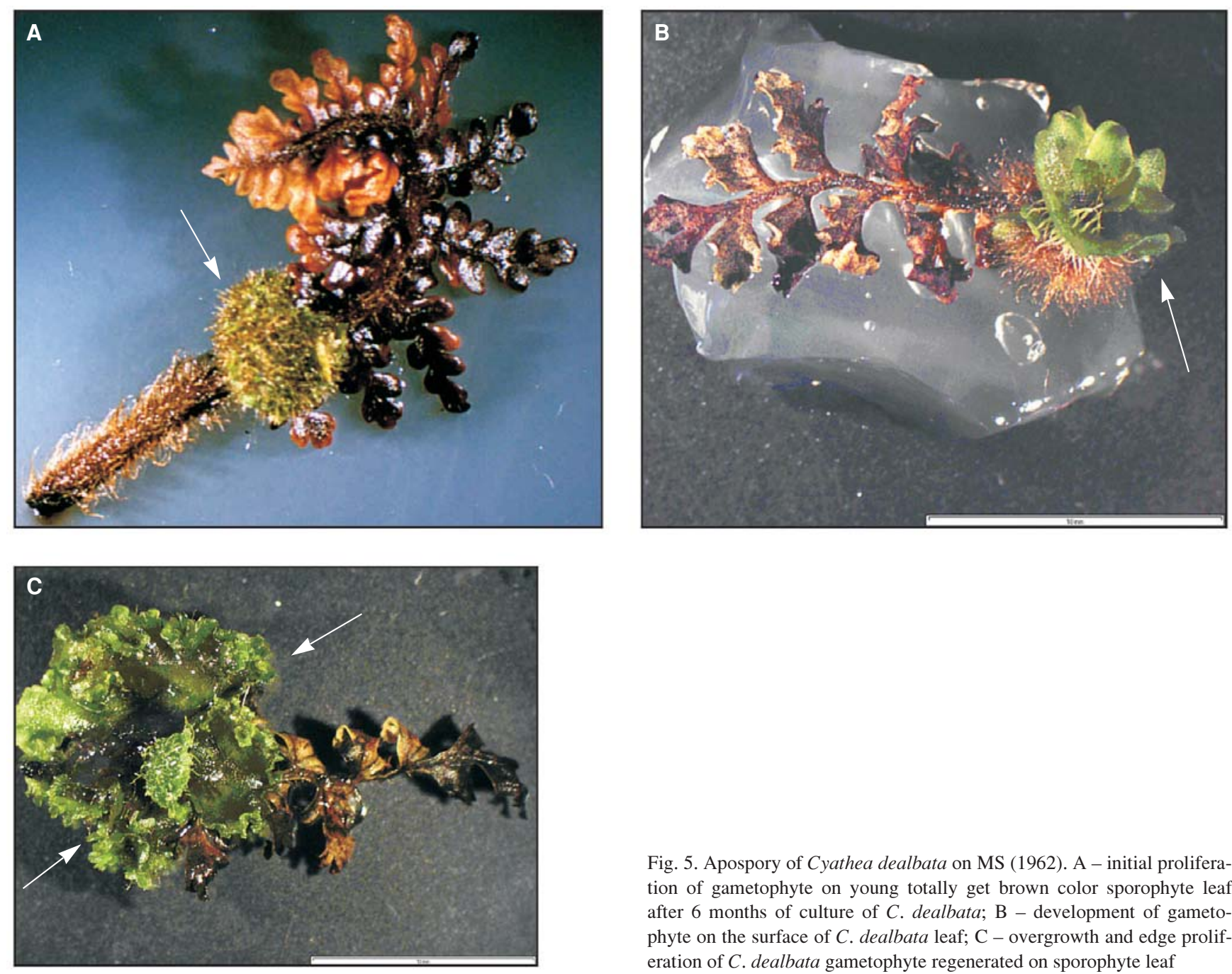

Fig. 5. Apospory of Cyathea dealbata on MS (1962). A - initial proliferation of gametophyte on young totally get brown color sporophyte leaf after 6 months of culture of C. dealbata; B - development of gametophyte on the surface of $C$. dealbata leaf; $\mathrm{C}$ - overgrowth and edge proliferation of C. dealbata gametophyte regenerated on sporophyte leaf

\section{LITERATURE CITED}

CONSTANTINO S., SANTAMARIA L.-M., HODSON E. 2000. Storage and in vitro germination of tree fern spores. Botanic Gardens Micropropagation News. 2 (4): 58-60.

DYER A.F. 1979. The culture of fern gametophytes for experimental investigation, pp. 253-305 in A.F. Dyer. The experimental biology of ferns. Academic Press, London.

DOUGLAS G.E., SHEFFIELD E. 1990. A new technique for the culture propagation of fern gametophyte. Plant Cell Reports 8: 632-634

ETTER A. 1993. Diversidad ecosistémica hoy. In: Neustra Diversidad Biológica. Cerec and Fundación Alejandro Angel Escobar, Bogotá, pp. 296.

FERNANDEZ H., BERTRAND A.M., SÁNCHEZ-TAMÉS R. 1997. Gemmation in cultured gametophytes of Osmunda regalis. Plant Cell Rep. 16: 358-362.

GOMEZ L.D. 1983. Cyatheaceae and Dicksoniaceae (Rabos de Mico, Tree Ferns). In: Janzen D.H. (ed.) Costa Rican Natural History. The University of Chicago Press, pp. 816.

GOLLER K., RYBCZYŃSKI J.J. 1995. In vitro culture used for tree fern Cyathea australis (R.Br.) Domin vegetative propagation. Acta Soc. Bot. Pol. 64: 13-17. 

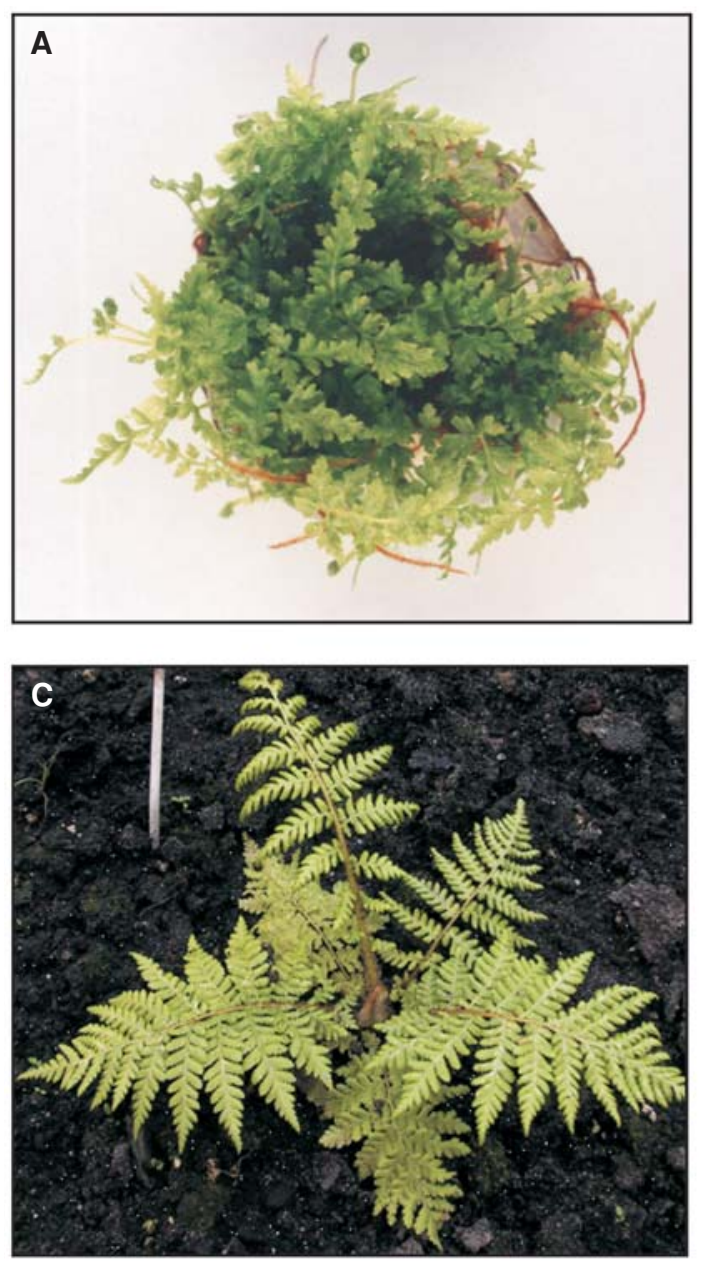
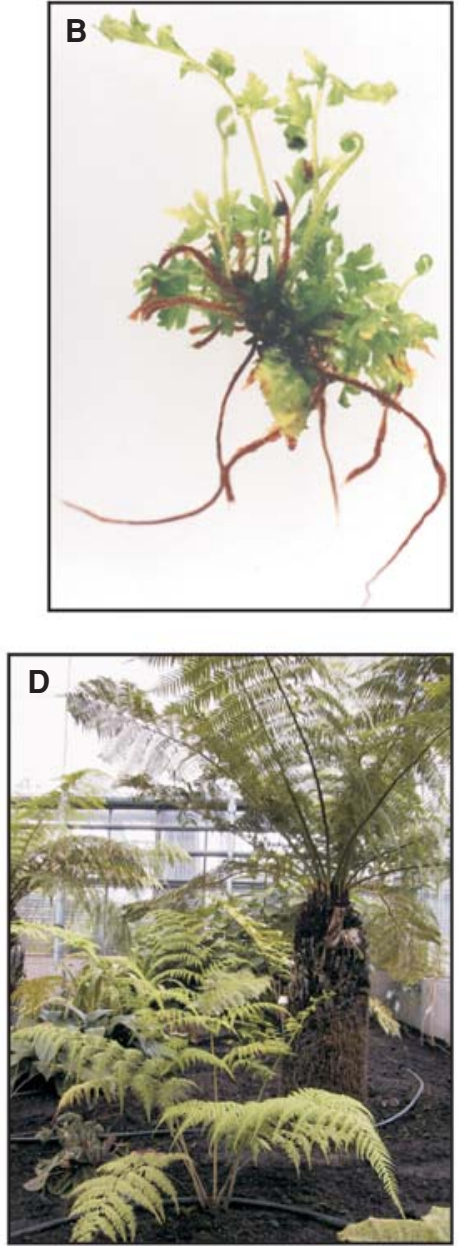

Fig. 6. Stages of sporophyte development. A - the effect of spontaneous fertilization and production numerous very young leaf in Cibotium schiedei; B - single young sporophyte of Cibotium schiedei with leaves; $\mathrm{C}$ young $C$. australis in greenhouse collection in soil; D - old and young tree ferns in our tropical greenhouse
HIRSCH A.M. 1975. The effect of sucrose on the differentiation of excised fern leaf tissue into either gametophytes or sporophytes. Plant Physiol. 56: 390-393.

KRAMER K.U. 1990. Cyatheaceae. In: Kramer K.U., Green P.S. (eds) Pteridophytes and Gymnosperms Vol. 1. Kubitzki K. (ed.) The Families and Genera of Vascular Plants. SpringerVerlag, pp. 404.

LLOYD R.M., KLEKOWSKI E.J. 2000. Spore germination and viability in pteridophytes: evolutionary significance of chlorophyllous spores. Biotropica 2 (2): 129-137.

MARCONDES-FERREIRA W., FELIPPE G.M. 1984. Effect of light and temperature on the germination of spores of Cyathea delgadii. Revista Brasil. Bot. 7: 53-56.

MURASHIGE T., SKOOG F. 1962. A revised medium for rapid growth and bioassays with tobacco tissue culture. Physiol. Plant. 15: 473-497.

PAGE C.N. 1979. Experimental aspects of fern biology, pp. 552585 in A.F. Dyer. The experimental biology of ferns. Academic Press, London.
RANDI A.M., FELIPPE G.M. 1988. Efeito do armazenamento de espores, da aplicaçăo de DCMU e da pré-embebiçăo em PEG na germinaçăo de Cyathea delgadii. Ci. and Cult. 40: 484-489.

SIMABUKURO E.A., DYER A.F., FELIPPE G.M. 1998. The effect of sterilization and storage conditions on the viability of the spores of Cyathea delgadii. Am. Fern J. 88 (2): 72-80.

TRYON R. 1976. A revision of the genus Cyathea. Contributions from The Gray Herbarium of Harvard University No. 206, pp. -101 .

ZENKTELER E. 1995. Some aspects of alternation of haploid phase in ferns life cycles. VII Conference of Plant Embryologists of Czech Republic, Slovakia and Poland. 14-16 IX 1995, Lublin, 59. 